\title{
Trait-Based Root Phenotyping as a Necessary Tool for Crop Selection and Improvement
}

\author{
Rebecca K. McGrail ${ }^{1}\left(\right.$, David A. Van Sanford ${ }^{2}$ and David H. McNear Jr. ${ }^{1, *}$ \\ 1 Rhizosphere Science Laboratory, Department of Plant and Soil Sciences, University of Kentucky, Lexington, \\ KY 40546, USA; rebecca.mcgrail@uky.edu \\ 2 Wheat Breeding Group, Department of Plant and Soil Sciences, University of Kentucky, Lexington, KY 40546, \\ USA; dvs@uky.edu \\ * Correspondence: dave.mcnear@uky.edu
}

Received: 15 July 2020; Accepted: 31 August 2020; Published: 4 September 2020

\begin{abstract}
Most of the effort of crop breeding has focused on the expression of aboveground traits with the goals of increasing yield and disease resistance, decreasing height in grains, and improvement of nutritional qualities. The role of roots in supporting these goals has been largely ignored. With the increasing need to produce more food, feed, fiber, and fuel on less land and with fewer inputs, the next advance in plant breeding must include greater consideration of roots. Root traits are an untapped source of phenotypic variation that will prove essential for breeders working to increase yields and the provisioning of ecosystem services. Roots are dynamic, and their structure and the composition of metabolites introduced to the rhizosphere change as the plant develops and in response to environmental, biotic, and edaphic factors. The assessment of physical qualities of root system architecture will allow breeding for desired root placement in the soil profile, such as deeper roots in no-till production systems plagued with drought or shallow roots systems for accessing nutrients. Combining the assessment of physical characteristics with chemical traits, including enzymes and organic acid production, will provide a better understanding of biogeochemical mechanisms by which roots acquire resources. Lastly, information on the structural and elemental composition of the roots will help better predict root decomposition, their contribution to soil organic carbon pools, and the subsequent benefits provided to the following crop. Breeding can no longer continue with a narrow focus on aboveground traits, and breeding for belowground traits cannot only focus on root system architecture. Incorporation of root biogeochemical traits into breeding will permit the creation of germplasm with the required traits to meet production needs in a variety of soil types and projected climate scenarios.
\end{abstract}

Keywords: roots; root system architecture; crop selection; plant breeding; phenotyping

\section{The Need for Root Breeding}

The global population is projected to reach nine billion people by 2050 and eleven billion people by 2100 [1]. Food production must increase in conjunction with the population. This scenario is similar to the population boom following World War II that ushered in the Green Revolution. In the mid-twentieth century, the worldwide population growth, especially in developing countries, did not keep pace with food production. Yield increases in grain crops, the staple of many diets in developing countries, were limited by poor growth responses to fertilizer [2]. Grain crops frequently lodged in response to fertilizer additions and could not be harvested. The development of semi-dwarf varieties of wheat and rice, which exhibited decreased lodging in response to nitrogen fertilizer, greatly increased grain yield. Semi-dwarf varieties of wheat directly resulted in a $208 \%$ increase in yield in developing 
countries between 1960 and 2000 [3]. This advancement in breeding supported growing worldwide populations while also ensuring developing countries could produce enough food.

Such a remarkable increase in grain crop yield necessary for the next revolution in crop production will not arise from fertilizer addition alone. Opportunities to improve crop yields are greatest in developing countries because of large yields gaps [2]. Fertilizer prices are volatile and can increase in response to increasing fuel prices, making them economically unattainable for many producers [2]. Further, mineral-based fertilizers, such as phosphorus, are finite; Isherwood [4] projected that reserves of phosphate would be depleted within 80 to 100 years, assuming current consumption rates, failure to locate new reserves, and current economic feasibility for extraction. Decreasing reserves of mineral fertilizers impose significant economic burdens on developing nations. Further, fertilizer use efficiencies for macronutrients are low. Efficiencies of added nitrogen, phosphorus, and potassium are $\leq 50 \%, \leq 10 \%$, and $20-40 \%$, respectively [5]. Yield gaps can be decreased worldwide through wise use of fertility inputs, the adaption of management practices, which conserve or enhance fertility, and adaptation of germplasm for low-fertility soils and for low input conditions [2].

Understanding the extent to which selection for aboveground traits has influenced root systems in conjunction with input-intensive systems will be important for future improvement of plants for low fertility soils and low input practices [6]. Crop breeders have considered nutrient use efficiency (NUE) as an improvement strategy. NUE is broadly defined as the ratio of produced outputs relative to nutrient inputs [7]. NUE can be further broken down into specific efficiencies based on the measured outputs and inputs: partial factor productivity, partial nutrient balance, agronomic efficiency, apparent nutrient recovery efficiency, internal utilization efficiency, and physiological efficiency [7]. NUE, however, is a complex quantitative trait that can be difficult to incorporate into breeding programs due to high environmental variation in field plots. Nutrient acquisition efficiency (NAE), referring to the physical placement of the roots where the target resource (e.g., $\mathrm{P}, \mathrm{H}_{2} \mathrm{O}$ ) is located in the soil profile, is a promising breeding target for four primary reasons, as proposed by Lynch [2]: (1) shoot traits, which affect NUE, can be confounded with other targeted traits; (2) NUE has been indirectly selected through breeding for yield potential; (3) root traits related to NAE may have been subjected to neutral or negative selection unknowingly as a result of breeding in high-input conditions to reduce environmental variation; (4) root traits related to NAE have not been used as a selection criterion in plant breeding because of difficulties in developing screening methods.

With respect to the confounding of NUE-related traits, the connection between shoot/leaf traits and root traits is poorly understood and oversimplified [8]. This lack of understanding is a result of little data on the correlations between aboveground and belowground traits [9]. Studies attempting to correlate aboveground and belowground metrics often reach differing conclusions, likely due to the traits studied. Studies that correlate root and leaf nutrient concentration consistently reach similar results [10-12], which is logical since roots are directly responsible for the uptake of nutrients that are then partitioned to leaves. Confusion arises, however, when studies attempt to correlate other traits, particularly leaf area or nutrient content, with root length. Root length is widely accepted as a measure of a plant's ability to acquire belowground nutrients [13]; it is, therefore, logical to correlate root length with aboveground traits. However, roots are nimble in their response to soil resources and will adjust their growth in response to resource heterogeneity and/or concentration. For example, Ryser and Lambers [14] found that grasses responded to decreased nitrogen and phosphorus stress by decreasing root length and increasing the root area. Additionally, plants under nutrient stresses may reduce leaf thickness in order to increase leaf area [14]. Utilizing observations of increased leaf area as a proxy for decreased root length in response to nutrient stress does not hold for all plants under nutrient stress and even for plants that are without stress. Plants not under nutrient stress may have increased leaf area and a longer root system. Variation in both leaf area and root length are functions of biomass allocation to the receiving organ, the thickness of the organ, and the volume of the tissue-mass density of the plant [14]. Therefore, care must be taken when correlating root-specific and leaf specific traits. 
The relationship between root traits and shoot/leaf traits is further confounded by breeding. NUE has been indirectly selected through breeding for yield potential because of the environment in which selection most often occurs. Root traits related to NAE may have been subjected to neutral or negative selection unknowingly as a result of breeding under these high-input conditions. Breeding programs typically produce crosses under fertilized and irrigated conditions in order to reduce environmental variation and promote the greatest expression of genotypic variation possible for further selection. Continued crosses and propagation of lines under these conditions may have inadvertently resulted in changes to root traits by unknowingly selecting plants with decreased ability to prime for nutrients not supplied as fertilizer. Variety trials designed to evaluate yield response, lodging, and other shoot traits under high fertility may mask poor root performance. For example, Gaines and Nugaines, two of the first varieties of semi-dwarf wheat, produced poorly when adopted outside of the high rainfall of Washington State, where they were developed and outside of irrigated conditions in which they were tested [15]. This was an early indication that root system architecture (RSA) may have been unintentionally and negatively impacted when breeding for shoot-specific traits. Numerous studies on semi-dwarf and non-dwarf wheat have identified changes in rooting depth. With the exception of a 1968 study, all studies have concluded that non-dwarfed wheat has greater root length [15-18]. The results of the conflicting study in which a tall variety of wheat produced a shallower root system than a semi-dwarf and full dwarf variety [19] are likely the result of phenotypic variation induced by environmental conditions. For many of these early studies, roots are often considered a $C$ sink and only function to reduce assimilates partitioned to grain or aboveground biomass. As such, the goal in breeding is to minimize the $C$ allocation to the roots to maximize yield, an effort with unknown consequences below ground.

While aboveground and belowground biomass is considered to be approximately equivalent, except in poor nutrient or climatic conditions [20], breeding for decreased stature has corresponded with changes to root system architecture. Root cell expansion in Arabidopsis thaliana is regulated by the DELLA gene [21], which is an ortholog of the dwarfing genes used to reduce stem height in wheat and other cereals [18]. Additionally, genomic analysis has identified several chromosomal hotspots for seminal root angle selection near chromosomal regions for dwarfing [22]. Seminal roots are extremely important in wheat. Seminal roots are functionally active for the entire life of the wheat plant [23]. While seminal roots can grow deeper than nodal roots, nodal roots fail to develop in some cases, such as drought, and seminal roots support the plant through physiological maturity [23]. The seminal root angle has been correlated to root system growth and function [22]. Changes to the seminal root angle due to dwarfing may have impacted root function. Other quantitative trait loci (QTL) for several root architectural traits-seminal root number, seminal root length, total root length, maximum width, maximum depth, and emergence angle-have been identified on the same chromosomes as the seminal root angle QTL identified by Richard et al. (2018) [24].

Additional studies focused on root traits related to NAE, such as root angle and branching, juxtapose well with studies on rooting depth. Significant differences have been observed in root biomass among old and modern varieties of wheat; old varieties can have up to three times greater biomass than semi-dwarf cultivars [25]. Evaluation of Turkish modern cultivars and landraces has found significantly greater total root biomass, shallower root weight, and a greater mass of roots deeper in the soil profile [26]. The finding of greater root biomass in landraces compared to modern varieties of wheat is consistent with the findings of Siddique et al. [27] and Waines and Ehdaie [28], who found that root biomass and size of the International Maize and Wheat Improvement Center (CIMMYT)-derived bread wheats were significantly smaller than drought-tolerant landraces for every variety analyzed. Further, shallower crown angles have been identified in modern varieties of wheat compared to wild emmer and varieties released prior to the introduction of dwarfism [29]. Shallow crown root angles and smaller root diameters are indicative of a predominately horizontal root system consisting of fine roots, which would be highly advantageous in production systems in which fertilizers are applied or in no-till systems. There are, however, several drawbacks to plants having predominately horizontal 
root systems. Horizontal root systems would decrease terminal drought tolerance as the surface layers of the soil dry more quickly and place the plant at greater risk of damage with rapid changes in soil temperature at the surface. Many ideotypes can contribute to better nutrient acquisition in cereal crops. Lynch [30] proposed six root ideotypes advantageous for water and nitrogen uptake in maize, but many of the proposed ideotypes are relevant to other cereal crops and other resources. For example, a root system composed of an intermediate number of seminal roots with steep growth angles, large diameter, and few laterals with increasing lateral branching density would provide a balance between exploration of the surface soil and deeper soil layers.

Finally, root traits related to NAE have not been used as selection criteria in plant breeding because of difficulties in developing screening methods. Screening methods for NAE of roots have been discussed in greater detail later in this article. Root traits related to NAE are an untapped source of phenotypic variation that can be introduced into breeding lines. Increased yield has been the primary breeding objective in grain. However, yield is a highly complex trait with numerous genetic controls and is characterized by low heritability and high genotype by environment interaction [31]. Current efforts to increase yield are primarily focused on evaluating the response of shoot-specific traits to increasing radiation use efficiency, increasing photosynthetic capacity, and optimization of assimilate partitioning to the grain [32]. Principal traits of focus include selection for long coleoptiles, broad seedling leaves, embryo size, specific leaf area, large coleoptile tillers, fast emergence, fast leaf expansion rate, large grain, low-temperature tolerance, crown depth, and leaf area ratio [32]. Under these targets, only the depth of the crown roots is considered important, which does not provide information on the functionality of the root system. The role of RSA and its function in acquiring resources to support increased shoot growth are not considered when setting breeding targets. Several studies on root traits suggest that they are more heritable than yield and are suitable for incorporation into breeding programs [33-37].

Traits with high heritability values can be improved more rapidly and with less intensive evaluation than those with lower heritability [38]. Heritability estimates of root traits vary based on the methodology used. While lab-based estimates of heritability may be artificially inflated due to greater experimental control of conditions in the lab compared to the field, estimates from the literature generally support the potential for breeding for root-specific traits. Seminal root angle, the angle between the roots emerging directly from the embryo, has been correlated with the depth of rooting in wheat [37], sorghum [36], maize [39], and rice [34]. Several QTLs that could be used to target that trait have been identified in these crops and appear to be homologous. Seminal root angle is highly heritable in spring wheat, with values ranging from 0.52 to 0.65 depending on the methodology [40]. While seminal root angle is predominately applied in breeding programs focused on improving drought tolerance, root angle is also important in agricultural systems in which fertilizer is banded, or nutrients are not readily mobile, such as phosphorus. Genetic and error variance were the predominant sources of variance in the Richard et al. [40] study, which further supports the ability to utilize targeted breeding of root traits. High heritabilities of root traits have been found in other grain crops. Primary root length, diameter, surface area, and volume; crown root length; seminal root length and number; lateral root length and number; and dry weight are highly heritable in maize with heritabilities greater than 0.60 for all traits and all time points assessed [35]. This study has additionally classified the maize accessions as high performing and low performing based on the measured root traits for further work, such as marker determination. While heritabilities of these traits are promising for crop breeding, it is important to note that these lab-determined heritabilities will likely not hold true in the field. Both aboveground and belowground traits exhibit decreased heritability under stressed conditions [41]. Environmental variability will also influence the heritability of traits in the field. However, the overall high heritabilities of root traits in many species suggest that root traits are a good target for crop improvement [42-45].

Root systems provide numerous ecosystem services that will become more critical with increasing global population and a changing global climate. Soils contain three times as much carbon as vegetation 
and twice as much carbon as the atmosphere [46]. Soil carbon is derived largely from either the decomposition of plant residues, including roots, or through root exudation. Soil carbon directly contributes to water holding capacity, aeration, bulk density, nutrient holding capacity, and soil stability. Therefore, better root systems promote carbon sequestration and improve soil tilth for continued crop productivity. An often-overlooked input of plant roots is their contribution to the nutrient content of soil and the nutrient needs of the preceding crop, particularly when in no-till management. A better understanding of the physical and chemical properties of different crop roots would make possible the inclusion of roots in nutrient calculations and improve model predictions of the contribution of roots to soil C stocks. Further, root systems could be utilized to translocate mobile nutrients, such as nitrate, that have leached deeply into the soil profile back toward the soil surface, thereby reducing groundwater pollution. Lastly, root systems are essential in water storage and movement throughout the soil. Water infiltration is greater in soils with high soil carbon. During heavy precipitation events, such soils would more adequately intercept and store water, decreasing overland flow, which contributes to flooding. Greater water holding capacity would provide more water for crops. Root breeding for both physical and chemical traits is essential for increasing yield and improved agroecosystem function.

\section{Current Efforts for Root Breeding}

\subsection{Field-Based Phenotyping for Root System Architecture}

Observation and direct measurement of RSA in situ are difficult, and root traits related to NAE have not been used in plant breeding as a result. Yet increased interest in the genetic potential of roots has resulted in the development of several methodologies for evaluating RSA. Root systems are complex as they are three-dimensional systems, which can be characterized by individual traits, such as root type, number, diameter, length, and degree of branching, among others, or by composite traits, such as network perimeter, network volume, or business [47]. The phenotyping method chosen will determine the number and resolution at which variables can be measured.

There are two approaches to assessing RSA: field-based or lab-based phenotyping. Each offers benefits and has disadvantages for root breeding. The field-based methodology can be utilized alongside breeding field trials so that both aboveground and belowground traits can be assessed together under field conditions. This would allow changes in RSA to be correlated with aboveground selection. In-field phenotyping often prevents the direct viewing of the entire root system and is generally a one-time measurement of the root system, with the exception of mini-rhizotrons (Figure 1).
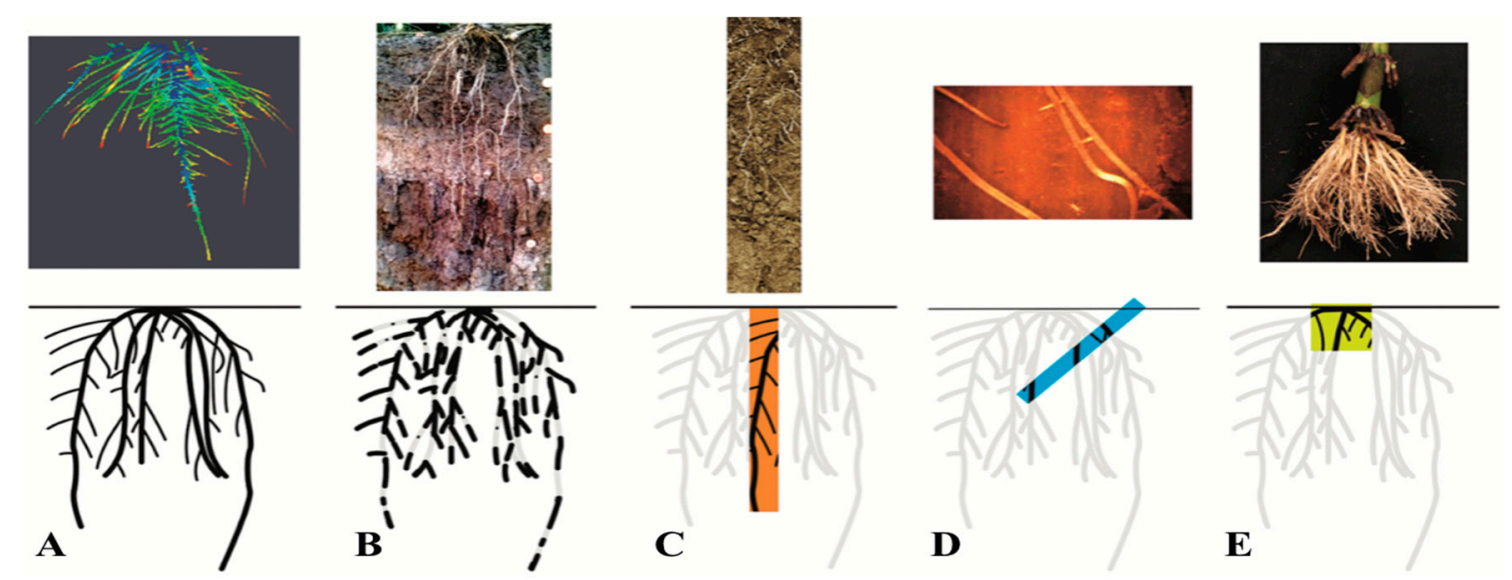

Figure 1. Summary of root system architecture captured by various methods: (A) full root phenotype, (B) trenching, (C), coring, (D) mini-rhizotrons, (E) crown root excavation. Black outlining of the root system indicates regions that could be viewed for phenotyping. Colored bars indicate the region of sampling. The figure is reproduced with permission from Topp et al. [6]. 
One of the earliest field-based phenotyping methods was the construction of trench profiles in which the root system is excavated layer by layer horizontally (Figure 1B). Trench profiling was pioneered by Dr. John Weaver in prairie and crop systems 100 years ago [48]. Using the trench method, the root system is characterized and measured manually in two-dimensions at a single time point, usually at or before harvest. Weaver painstakingly illustrated each root system profiled in beautiful detail while also collecting physical measurements. Trenching provides an accurate measure of the extent (width, depth, etc.) of the root system in its natural setting from which other metrics (e.g., biomass) could be inferred. While trenching could be carried out after harvest, doing so would result in an underestimate of root number and biomass due to the turnover of fine roots at physiological maturity and the onset of reproduction. While trenching is probably the most comprehensive method, it requires a great deal of time and effort to excavate and measure. As such, trenching would be nearly impossible to incorporate into breeding field plots. Breeding field plots are harvested to measure yield and select for other agronomic shoot traits of importance. Trenching would prevent machine-harvesting or would require trenches to be filled before harvest, further increasing the amount of time associated with this method.

Shovelomics has gained popularity as a rapid field-based root phenotyping tool (Figure 1E). Shovelomics is the standardized excavation of plant root crowns to a depth of $\sim 25 \mathrm{~cm}$ (plant-dependent), followed by careful washing and then the determination of root angle, lateral root numbers using a phenotyping board in the field [49], and/or more detailed parameters using software, such as DIRT [50], RootReader [51], WinRhizo [52], or GiA Roots [53], in the laboratory. Shovelomics has been used for a number of crops, including wheat [54], maize [49], and common bean [55], to select for plants with shallow root phenotypes for interception of nutrients (e.g., P) in the topsoil or for plants with steep root angles for the interception of water and other resources deeper in the profile. This method has been used in breeding field plots without impacting the collection of shoot agronomic traits. However, measurements are destructive and can be highly variable, requiring significant sample replication [56]. Despite these shortcomings, shovelomics remains a good alternative to more labor-intensive (trenching) or less resolved (coring) methods of field-based phenotyping.

Cores, unlike trenches and shovelomics, rely on roots washed from sections of a 2-3-inch diameter by 1-2 $\mathrm{m}$ deep soil core to estimate root distribution in the soil profile. While many cores can be rapidly collected from a field site, there are some significant limitations to how this data is interpreted. Because the cores only provide a two-dimensional vs. a three-dimensional representation of the roots, cores can miss portions of the root system and underestimate both its depth and breadth. Further, it is difficult to determine root ontogeny and architecture because the sample has been isolated from the plant. Cores may also contain small pieces of root branches without the main root or may contain pieces of neighboring plant roots. Missing root pieces or inclusion of extraneous pieces could result in a misrepresentation of the root system as, for example, root branching has been identified as the causal factor for root trait variation among grass species [57]. The growth stages at which the cores are collected could also influence the measurements. Sampling late in the growing season would underestimate the root number and biomass because of fine root turnover at physiological maturity and the onset of reproduction. This could be overcome by taking multiple cores throughout the growing season, but care would have to be taken to prevent cores from altering plant growth. Trenching has been paired recently with periodic coring [58]. Using this method, cores would be taken throughout the growing season to estimate root number and biomass at each depth interval, a trench dug at harvest to evaluate the full extent of the root system, and then digital reconstruction of roots can be made and used in modeling. Lastly, soil chemical and physical heterogeneity must be considered in all field-based root phenotyping methods as the interactions between the root and the surrounding soil can contribute significantly to measurement error. The collection and washing of cores and other partial-view methods prevent viewing of the soil structure and its possible influences on the root system. For example, root avoidance of compacted layers, rocks, or poorly drained/aerated zones would be missed. 
There are several non-destructive methods that have been explored for imaging root distribution and architecture without the time and resources necessary for excavation. Ground-penetrating radar has been explored for infield imaging, but resolution limitations currently restrict its use to trees and woody plants with thicker roots [56]. Minirhizotrons have been utilized in numerous field studies of RSA. Minirhizotrons require the insertion of viewing tubes into the soil before planting or as early as possible after planting of annual crop plants. Inserting the tubes early enough prevents damage to the existing root system and allows the soil to settle and roots to grow around the viewing tube [59]. Minirhizotrons are generally inserted at a $45^{\circ}$ angle to encourage root contact while minimizing preferential root growth along the viewing tube, or poor root contact as might result in the vertical placement of tubes [60]. Specialized scanners or cameras are then lowered into the minirhizotron viewing tube, which permits almost a full $360^{\circ}$ view of the roots in contact with the viewing tube. Minirhizotrons offer the best assessment of roots in-situ while also allowing for equipment operation and for the harvesting of breeding trial plots. Minirhizotron viewing tubes can be of any length necessary, requiring that multiple images be collected from the same tube. Images collected will also provide information about the surrounding soil, such as the formation of redoximorphic features, avoidance of a soil region (e.g., hardpan or fragipan), or association with symbiotic organisms (e.g., mycorrhizae), which may be used to guide sampling and further study. However, collected images are not a complete rendering of the root system; images are a two-dimensional representation of a portion of the root system in contact with the tube from which estimates can be made of the extent of the remaining root system.

\subsection{Lab and Greenhouse-Based Phenotyping for Root System Architecture}

Lab and greenhouse-based phenotyping techniques have been developed to reduce variability resulting from climate and the heterogeneous nature of the soil in the field. One benefit of lab or greenhouse-based phenotyping is the in-situ characterization of roots without destructive sampling. Roots can be imaged over an entire growing season without negatively impacting plant growth, which is generally more labor-intensive and time consuming compared to single-point field measurements. The method selected to do so is generally restricted only by container size [56]. Electrical capacitance [61,62], electrical resistance tomography [63,64], magnetic resonance imaging [65,66], positron emission tomography $[67,68]$, X-ray computed tomography $[69,70]$, and minirhizotrons have been used to image soil-grown plants in laboratories and greenhouses.

Similar to field-based methods, the method selected can provide either two-dimensional or three-dimensional information. Electrical capacitance (EC), electrical resistance tomography (ERT), and minirhizotrons (discussed in detail previously) provide two-dimensional information. EC actively polarizes the root epidermal membranes through an external energy source and measures the resulting dielectric properties to reconstruct the root system [71]. Unlike other methods in which water content hinders the ability to detect roots, EC requires the soil to be saturated. Roots must be in contact with soil solution to be measured [61]. Poor root contact with soil solution will result in the underestimation of the root surface area. As it is non-destructive, this method can be used to measure RSA multiple times throughout a growing season. However, the same EC model cannot be used for all plants [61]. The influence of surrounding plants, root density, and physiological maturity on EC measurement is not well understood. ERT relies on the opposing theory to EC. Rather than measuring the capacitance under an induced electrical current, ERT measures resistivity to map soil water profiles [72]. Measurements can be converted into a three-dimensional model if the measurements are of high enough resolution [73]. To date, ERT has been used primarily for plants with large diameter roots, such as trees, to estimate root biomass $[63,74,75]$. It has been applied to maize and sorghum to assess water dynamics [64]. Estimates of other root properties, such as diameter, would be difficult to extract from measurements taken using this technique.

Magnetic resonance imaging (MRI), positron emission tomography (PET), and X-ray computed tomography (X-ray CT) provide three-dimensional information. MRI relies on a strong magnetic field and radiofrequency fields to align protons $\left(\mathrm{H}^{+}\right)$in tissues [76]. Manipulation of parameters allows 
water contained in plant tissues and in the soil matrix to be distinguished [67]. High water content may prevent the imaging of fine roots and root hairs [77]. However, the reduction in resolution due to water content is dependent on soil type. Pflugfelder et al. [66] were able to image barley roots as small as $300 \mu \mathrm{m}$ in five soil types at water holding capacities of $50-80 \%$. Although high-quality images require a low background concentration of ferromagnetic materials [76], this technique would not be well suited for soils highly enriched in iron, cobalt, or nickel. MRI has been used to image RSA in a variety of crops, including maize and barley by van Dusschoten et al. [65] and sugar beet by Metnzer et al. [78].

PET constructs a three-dimensional image by detecting the distribution of gamma rays from radioactive tracers with short half-lives [72]. A carbon tracer $\left({ }^{14} \mathrm{C}\right)$ is often used because it is assumed to partition and to behave similarly to ${ }^{12} \mathrm{C}$ and ${ }^{13} \mathrm{C}$ in metabolic processes [68]. Despite high sensitivity for the tracers currently used, the resolution is constrained to approximately $1.4 \mathrm{~mm}$, which would limit the detection of many roots [67]. PET is often coupled with other tomographic techniques, such as MRI and X-ray CT, to improve detection. PET coupled with X-ray CT has been used to image fodder radish RSA in sand [68]. Fodder radish, sugar beets, and maize RSA have been imaged with PET-MRI [67].

X-ray CT utilizes differential attenuation of X-rays to create a cross-sectional, three-dimensional image of root systems [72]. The reconstruction relies on the principle that the source X-ray will be returned from differing components, such as roots and soil minerals, at differing intensities. High water content may reduce the accurate imaging of fine roots and root hairs [77]. The ability of X-ray $\mathrm{CT}$ to image roots was demonstrated over 30 years ago [79]. Improvements in scan time, resolution, reconstruction, and software have greatly improved this technique for use with soil-grown plants [69]. X-ray CT resolution has improved to the point that interacting winter wheat root systems can be teased apart with imaging [80]. The major limitations to X-ray CT are container size and access to an instrument. In applications in which medical X-ray CT scanners are used, containers may have to be placed horizontally for large plants to be imaged. Access can also be difficult due either to high instrument costs and demand or access around patient care if using the instrument at a local medical facility. Non-medical X-ray CT scanners do offer the possibility for vertical sample placement [72].

Many lab-based phenotyping methods utilize solution $[40,81]$ or agar $[51,82,83]$ instead of soil. Solution or agar-based methods allow for root systems to be easily measured at varying developmental stages to assess growth over time. There are many variants of solution-based root phenotyping systems ranging from simply suspending the plants in a nutrient solution in a beaker to more advanced hydroponic or aeroponic systems. Growth pouches can be advantageous as solution can be refreshed or changed, and there are existing procedures and systems for solution-based growth. However, data collected from these systems lack perspective, as roots do not have a spatial arrangement similar to soil.

Agar-based phenotyping systems, such as the one constructed by Iyer-Pascuzzi et al. [83], allow for the collection of a full three-dimensional image of the root system throughout development. Plants are grown in clear glass or plastic cylinders filled with agar, which allows for imaging roots in-situ using a rotary turntable to collect images through a full $360^{\circ}$ of rotation. Images can be collected as long as the plant remains viable and the gel remains sterile, or until roots have grown to the edge of the container. Agar systems can be constructed with homogenous distribution of nutrients, or they can be easily modified to evaluate root response to different nutrient availabilities/deficiencies and allocations. Agar-based phenotyping does have some drawbacks. Agar must be prepared to a resistance similar to that of soil so that roots can penetrate and adequate structural support is provided for the plant [84]. Agar, while a solid, does not have pore space like soil, which may influence root growth. Seeds inserted fully into agar can become sealed and lack enough gas exchange to promote germination [84]. Varying methods of planting have been utilized for gel-based systems to combat these problems. Studies utilizing gel-phenotyping have germinated seeds in Petri plates with media [85] or in nutrient solution [83] and have then inserted the seedlings into the gel for further growth. This method may artificially influence the root angle and can damage roots. The authors have successfully germinated winter wheat (Triticum aestivum L.) in agar so that the root angle is not artificially influenced. While 
agar-based phenotyping does not allow for the collection of chemical data, it is a superior method for the measurements of RSA.

\subsection{Marker-Based Profiling for Root System Architectural Traits}

Characterization of root system architecture for the selection of preferred phenotypes might be expedited by the identification of markers for use in marker-assisted selection. The high heritabilities of root traits would allow for rapid improvement if markers could be identified and would limit the amount of field-based or lab-based phenotyping needed to verify root system architectural traits. Differing genetic marker types may be more or less suitable for certain qualities. Genetic markers are broadly classified as classical and DNA/molecular-based markers. Classical markers include morphological, cytological, and biochemical markers [86]; molecular markers include restriction fragment length polymorphism, amplified fragment length polymorphism, simple sequence repeats, single-nucleotide polymorphism (SNP), and diversity arrays technology. There are benefits and drawbacks to the type of marker used. Molecular markers are reproducible but can be costly. Classical markers, on the other hand, can be visually assessed or do not require specific instrumentation. Classical markers can be influenced by environmental factors and may not make the best choice for root system traits. Therefore, much of the work on markers for root breeding has been focused on DNA markers.

Numerous molecular markers have been determined for root system architectural traits in several crops. A genome-wide association panel that used SNP markers has identified corn seedling root traits that could be beneficial in selecting mature plant traits, such as root dry weight, which positively correlates with mature plants, including yield, in both low and high nutrient conditions [87]. Heritability values obtained in this corn study are similar to those found in controlled greenhouse and growth chamber experiments and field experiments. Pace et al. [87] concluded that SNPs could be used to include root architecture in a breeding selection strategy. Further, quantitative trait loci (QTL) have been identified for use in marker-assisted selection strategies. Root length, volume, number, fresh weight, and dry weight QTLs have been determined for sorghum [44]. Wells et al. [81] identified twenty-nine QTLs for hexaploid wheat root traits, including seminal root angle, seminal root length, and total root length. The QTLs identified explain $7.1 \%$ to $26.8 \%$ of the variation with a varying magnitude of additive effects, suggesting that the identified markers may be useful in crop breeding. Further, QTLs for yield and nitrogen uptake verified in field studies co-localize with root QTLs on one chromosome, indicating root traits can likely be used to influence nutrient uptake and yield [81]. Thirty-eight QTLs associated with biomass and root architecture have been identified in oilseed rape grown under varying phosphorus conditions [45], indicating that root breeding could be a target for improved phosphorus acquisition. The QTL associated with responses to low phosphorus identified in oilseed rape have also been identified in Arabidopsis and share common genomic regions [45,88-90]. Continued work with Arabidopsis may prove beneficial in identifying possible markers for other crops, especially as the full genome has been sequenced, and QTLs identified in Arabidopsis appear to be homologous with other plants. The identification of several DNA markers, both QTLs and SNPs, for root traits supports root breeding.

\section{Importance of Looking Beyond Root System Architecture}

Focusing on the physical distribution of roots in the soil profile and making breeding selections to put roots where the resources are, is an essential first step to improving crop productivity. What should be included as a next or concurrent step in this process is an assessment of what the roots are doing once they get to the resource and what happens to the roots after crop harvest. The rhizosphere is a complex ecosystem shaped by plant species via physical root growth and the priming action induced by the chemical cocktail of root products entering the soil. These root products feed microbes, which drive nutrient cycles (i.e., priming) and influence water movement and nutrient uptake. After harvest, the roots then make an ill-quantified contribution to soil $\mathrm{C}$ and nutrient pools. 
This contribution is important in crop rotation and cover-cropping systems, especially where no-till or minimal-tillage is used, and the roots from the previous crop remain intact. Identifying how RSA-focused and shoot-specific breeding alters root structural and chemical properties is vital to achieving full yield potential.

\subsection{Structural Profiling}

Root system architecture should not be the only selection criterion for crop improvement. Plants partition $20-50 \%$ of fixed carbon to root systems [91], where it is used to build root tissues (e.g., lignin, cellulose, hemicellulose) or lost to the surrounding soil (i.e., rhizodeposits). As root systems remain in the soil profile after harvest, an understanding of the structural composition of roots is necessary to understand their turnover and subsequent influence on soil fertility. Coupling structural profiling with root system architecture will provide a better understanding of both placement of roots and the service those roots provide once the crop is terminated, such as nutrient release or incorporation into soil organic matter.

Root mineralization is not as well understood as mineralization of shoot tissues because roots are not easily observed. However, the same metrics used to estimate the mineralization of leaves and other tissues have been used to assess root mineralization, namely, the ratio of $\mathrm{C}$ to $\mathrm{N}$. The $\mathrm{C}: \mathrm{N}$ ratio, however, does not reflect how the carbon and nitrogen are distributed among root compartments. Carbon is partitioned to form root structural components, including cellulose, hemicellulose, and lignin, each with differing decomposability. Similar to the C:N ratio, the contents of cellulose, hemicellulose, and lignin vary with plant species. Maize, millet, sorghum, wheat, and other Poaceae species have lower lignin content than other botanical families, such as Brassicaceae and Fabaceae [92]. Low lignin content corresponds with a greater soluble fraction, which can be released for priming action [92]. Low lignin content is often viewed as a greater quality litter because it will rapidly decompose [93]. The purpose of the litter should be considered before selection in order to meet producer needs. Litter that will be serving as a cover crop in a highly weathering environment, such as one that receives a high amount of rainfall, must have more hemicellulose than litter that must degrade quickly to facilitate mechanical planting into the litter layer.

The soluble, cellulose, hemicellulose, and lignin fractions may be a better metric for estimating root quality than $\mathrm{C}: \mathrm{N}$ ratios. While root $\mathrm{C}: \mathrm{N}$ ratios vary between crop species, for example, 20 in dry pea to 75.2 in flax, C:N ratio has not been shown to vary with root depth within species [94]. Fine roots near the surface have the same carbon and nitrogen mass as deeper roots; however, their rate of turnover is quite different. Partitioning of carbon into cellulose, hemicellulose, and lignin is affected by the root type, age, and physiological stage of the plant. Lignin content has been found to increase with increased physiological age. The lignin content of wheat and maize roots increases significantly between flowering and maturity. A similar trend is identified in grasses in which lignin content varies across a growing season [57]. Many studies have found that fine roots decompose faster because of their lower lignin:nitrogen ratios [95]. Therefore, it is not the C:N ratio that is predictive of the rate of root decomposition, but instead, the chemical composition.

Nutrients may also be influential in predicting root turnover. Calcium content explains a large amount of variability in root decomposition [95]. Calcium regulates many cellular processes, including solute movement, cell division, cell wall synthesis, and structural function of support tissues [96]. Greater calcium content may indicate better quality tissues. Calcium availability can influence rooting patterns and nutrient uptake, specifically nitrogen [96]. The influence of calcium on root quality may be two-fold. Fungal and bacterial heterotrophs in close association with roots can accumulate calcium to form an oxalate salt [97] that can be used to maintain metabolism in unfavorable conditions [98] or be released to acquire nutrients during unfavorable conditions [99]. Additionally, calcium content may be reflective of conditions that influence decomposition [95]. Aluminum, boron, cadmium, copper, and manganese toxicities have been correlated with increased lignin concentration in rice, wheat, soybean, and tomatoes [100]. Deficiencies of calcium, potassium, manganese, nitrogen, phosphorus, 
and silicon correspond with decreased lignin content in wheat roots but increased lignin in tobacco and soybean [100]. Nutrients other than carbon and nitrogen, such as calcium or other elements of agronomic importance, should be considered during root assessments.

\subsection{Chemical Profiling}

The $30-60 \%$ of net fixed carbon in annual plants is transferred to roots [101]. The amount of this carbon exported into the rhizosphere as rhizodeposits varies by plant: $25 \%$ in wheat [102], $21 \%$ in barley [103], 52\% in maize [104], and 70\% in tomato [105]. Therefore, rhizodeposits should be considered when assessing roots during plant breeding. Exudates, such as phytosiderophores and enzymes, are critical for nutrient acquisition and uptake [106]. Assessment of root exudates in the soil is difficult due to soil matrix effects and microbial decomposition but have been successfully measured [107,108]. If lab-based phenotyping is used for the assessment of RSA, chemical profiling can be incorporated into the solution-based assessment of RSA, or solution-based profiling can be included in tandem with agar-based phenotyping.

Organic acids, or more appropriately organic anions because they are released as the conjugate base due to the $\mathrm{pH}$ of the root cytosol, are simple molecules with one or more carboxylic groups [109] that have been widely studied for their role in nutrient acquisition, pathogen resistance, and other abiotic and biotic stresses. The most frequently reported organic anions are those involved in the Krebs cycle and biochemical pathways responsible for important metabolites, such as oxalate, oxalo-acetate, malate, fumarate, succinate, $\alpha$-ketoglutarate, isocitrate, and citrate. Others, including formate and lactate, have also been observed [110]. The organic anion or anions exuded can vary with nutrient deficiencies [111]. Increased citrate and malate content of roots is reported for many plants under phosphorus deficiency [99], whereas acetate, formate, glycolate, malonate, oxalate, and piscidate aid in manganese acquisition [110]. The exudation of organic anions also varies by plant. For example, a study on alfalfa has recorded an $82 \%$ increase in citrate when in low phosphorus conditions [112], whereas rape has released malate instead [110]. Interpretation of these responses can be difficult as the cytosolic content of organic acids is 1000 -fold greater than in soil solution (i.e., $0.5 \mathrm{mM}$ compared to $0.5-10 \mu \mathrm{m}$ ) [99]. The low concentration in soil solution may be the result of microbial decomposition [43]. The release of organic acids in greater quantities than that consumed by microbial biomass will facilitate nutrient release from the soil matrix. Lastly, the variation of organic acid content by genotype has not been thoroughly evaluated [43] and may serve as a tool in crop selection.

The release of phenolics rather than organic anions is a strategy utilized by some plants when deficient in iron [113], but the release of phytosiderophores is the predominant strategy of grasses in iron-deficient conditions [114]. Chelation and solubilization of iron may additionally promote solubilization of phosphorous if iron oxide bound phosphorus is present. Additionally, phytosiderophores also chelate copper, zinc, and manganese, promoting the uptake of these micronutrients [115]. There is substantial variation in phytosiderophore release in cereals [116]. This variation could be utilized to select genotypes for certain environments or to breed better cereals. Differences in phytosiderophore production and micronutrient uptake are currently being utilized to combat global micronutrient deficiencies [2].

Enzymes are an additional acquisition strategy for a variety of nutrients. A suite of enzymes is exuded by plants, but much attention has been given to the role of enzymes involved in the acquisition of primary macronutrients, such as urease and nitrogenase for nitrogen and phosphatase and phytase for phosphorus. Barley genotypes exhibit significant differences in phytase [117] and phosphatase activity in P-limited conditions [118]. Wheat genotypes have also exhibited differential expression of acid phosphomonoesterase and phytase activities [119]. Greater acid phosphatase activity of wheat roots has been correlated strongly with the total phosphorus content of the plant $(r=-0.914)$ [120]. Such results support that the enzymatic activity of roots can be used as a screening parameter for nutrient utilization. 
An additional strategy to acquire nutrients is rhizosphere acidification. Liming of agricultural soils adjusts soil $\mathrm{pH}$ to an optimal range, one in which macronutrients and micronutrients for a given crop are most available. Due to the heterogeneous and dynamic nature of soils, $\mathrm{pH}$ varies and, therefore, nutrient availability differs throughout the soil profile. Acidification of the rhizosphere of specific roots serves to increase nutrient availability. Acidification of the rhizosphere is not solely a function of charge balance or organic acid exudation. It is an active pumping of $\mathrm{H}^{+}$ions. A study that has compared the acidification of iron deficient and sufficient plants found that there is no difference in organic acid exudation content of the roots. The observed $\mathrm{pH}$ change is attributed to organic acid accumulation as well as proton extrusion. The amount of protons required under the study conditions to achieve the $\mathrm{pH}$ change of 1.7 units is $43 \mu \mathrm{mol}$ [121]. The accumulated citrate and malate from one acidification cycle would theoretically yield $33 \pm 14 \mu \mathrm{mol} \mathrm{H}^{+}$, assuming citrate yields $2.5 \mathrm{H}^{+} \mathrm{mol}^{-1}$ and malate yields $2.0 \mathrm{H}^{+} \mathrm{mol}^{-1}$ [121]. Active proton extrusion is necessary to result in the observed $\mathrm{pH}$ change. Acidification is also responsible for the creation of a positive feedback loop in which the uptake of phosphate and ammonium is increased in maize [122,123]. Some crops, such as faba bean, rely on the mechanism more heavily than others. Under P deficiency, faba bean has a specific proton efflux of $0.47 \mathrm{nmol} \mathrm{h}^{-1} \mathrm{~cm}^{-1}$, whereas soybean has a specific proton efflux of $0.05 \mathrm{nmol} \mathrm{h}^{-1}$ $\mathrm{cm}^{-1}$ [124]. This difference in proton efflux explains the ability of faba bean to utilize sparingly soluble $P$ pools more effectively than soybean. However, acidification is not a nutrient acquisition strategy for all plants. Wild blueberry, highbush blueberry, and wild apple are not capable of acidifying their rhizosphere in response to iron deficiency $[125,126]$. Rhizosphere acidification is a targetable trait to increase nutrient acquisition.

\section{Future Perspectives}

Root traits are an untapped source of genotypic potential, and their use in selection criteria will likely enhance genetic gain. In the face of a changing climate and the need to feed eleven billion people by 2100, root breeding offers tremendous potential to plant breeders. Yet, there is not a "silver bullet" [127]; breeding for roots cannot rely on just one marker, gene, trait, or architectural component. There must be a holistic approach when incorporating roots into breeding programs. Roots serve a multitude of purposes and utilize numerous mechanisms to acquire nutrients and to support the plant, including secretion of enzymes, exudation of organic acids and chelators, and recruitment of beneficial microorganisms. Continued research into RSA, and importantly, coupling this with the assessment of structural composition and chemical traits of roots will aid in increasing crop yield by enhancing our selection of crops with better nutrient use and acquisition efficiencies, pest and disease resistance, and drought tolerance. By solely looking at RSA in root breeding, we are missing the opportunity to select for other desirable traits.

Just as roots do not rely on a single strategy, a single root system will not be ideal for every growing environment. The ideal root system for nitrogen acquisition will not be the same as the ideal root system for phosphorus due to the difference in mobility and location of these nutrients in the soil profile. Differing expressions of root growth have been shown in zones enriched or depleted in nutrients [128]. Further, roots utilize different mechanisms to acquire the same nutrient in different soils. For example, secretion of organic acids is important in calcareous soils in order to decrease soil $\mathrm{pH}$ and solubilize phosphorus, whereas the release of chelators and/or phytosiderophores is necessary for phosphorus acquisition in soils with large iron and aluminum concentrations. The expression of different acquisition strategies in different soils is further compounded by the influence of management on acquisition strategies. Shallower rooting systems with a high degree of lateral branching may be optimal in no-till systems where nutrients tend to accumulate in the surface layers; deep rooting may be advantageous in coarse-textured soils, which drain rapidly.

We propose a multi-faceted trait-based, resource-specific screening approach for the selection of desirable root phenotypes (Figure 2). Using this approach, the mechanisms known to be important for the acquisition of the target resource or suppression of the target pathogen/pest are predefined, 
and a population of plants is then screened for these traits in the lab and field-based experiments. For example, we know from the literature that the potential of a plant to extract phosphorus from the soil (we define this as the P extraction potential or PEP) is a function of a shallow root system for the interception, the release of phosphatase enzymes, protons, and organic anions (e.g., citrate, malate, oxalate), and recruitment of beneficial microorganisms (e.g., arbuscular mycorrhizal fungi). All of these traits can be quantified for a panel of plants while grown under low $\mathrm{P}$ conditions and included in a trait matrix used for the selection for those with the greatest PEP. Using this approach, one can imagine screening for the dominant trait (e.g., RSA) to put the roots where the resource is, then performing a secondary screening of the population for chemical, physical, and biological traits that then stack up (i.e., stackable-traits) to make a more robust phenotype. These mechanisms will not have the same efficacy across all soil types, but the potential can be adjusted for various environments. For example, the factor for citrate or malate content can be weighted more when calculating PEP for soils with low iron and aluminum oxide content, or the factor for RSA could be adjusted to decrease the weight of lateral branching for a tilled environment where phosphorus accumulation in the surface is not as prevalent as a no-till system. This holistic approach will support crop breeding for increased yield and nutrient acquisition necessary to feed a growing population with reduced mineral-based fertilizers.

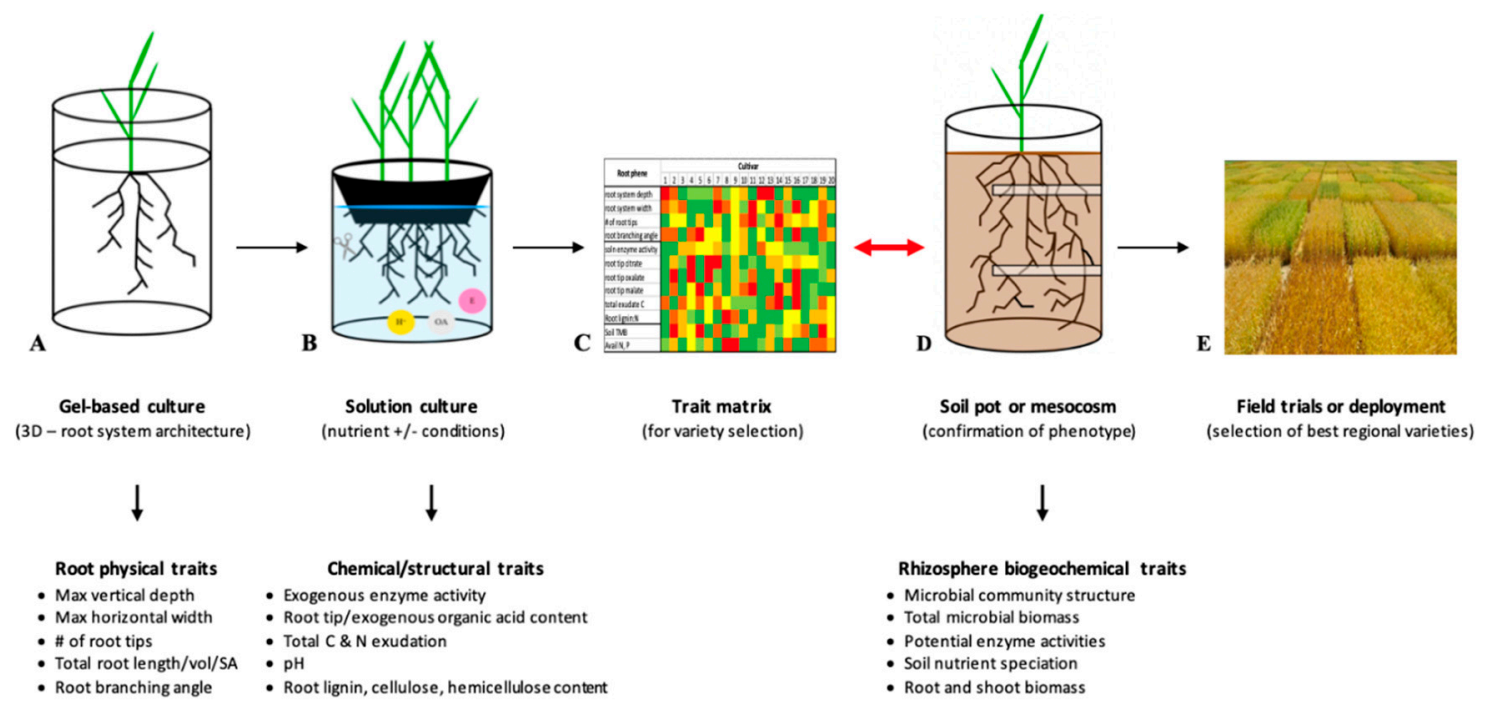

Figure 2. Summary of proposed trait-based phenotyping pipeline for crop improvement: 3D RSA in agar (A); solution culture for organic acid production in root tips, exported organic acids (OA), exported enzymes $(\mathbf{E})$, root composition, protons for acidification $\left(\mathrm{H}^{+}\right)$, and structural composition of roots/shoots (B); trait matrix used for resource-specific phenotype selection (C); pots/mesocosm controlled environment experiments for the verification of root phenotype and characterization of rhizosphere biogeochemical traits (D), which are added to the trait matrix and used to finally make a selection for field trials or deployment (E).

Author Contributions: D.H.M.J. devised the project. R.K.M. drafted the original manuscript with input from D.H.M.J. Editing and revising were conducted by D.H.M.J. and D.A.V.S. with R.K.M. All authors have read and agreed to the published version of the manuscript.

Funding: This research was funded by the United States Department of Agriculture National Institute of Food and Agriculture Grant 2016-67019-25281.

Conflicts of Interest: The authors declare that the research was conducted in the absence of any commercial or financial relationships that could be construed as a potential conflict of interest. 


\section{References}

1. United Nations, Department of Economic and Social Affairs, Population Division. World Population Prospects: The 2017 Revision, Key Findings and Advance Tables; Working Paper No. ESA/P/WP/248; United Nations, Department of Economic and Social Affairs, Population Division: New York, NY, USA, 2017.

2. Lynch, J.P. Roots of the Second Green Revolution. Aust. J. Bot. 2007, 55, 493-512. [CrossRef]

3. Pingali, P.L. Green Revolution: Impacts, limits, and the path ahead. Proc. Natl. Acad. Sci. USA 2012, 109, 12302. [CrossRef]

4. Isherwood, K.F. Mineral Fertilizer Use and the Environment; International Fertilizer Industry Association/United Nations Environment Programme: Paris, France, 2000.

5. Baligar, V.C.; Bennett, O.L. Outlook on fertilizer use efficienty in the tropics. Fertil. Res. 1986, 10, 83-96. [CrossRef]

6. Topp, C.N.; Bray, A.L.; Ellis, N.A.; Liu, Z. How can we harness quantitative genetic variation in crop root systems for agricultural improvement? J. Integr. Plant Biol. 2016, 58, 213-225. [CrossRef] [PubMed]

7. Sarkar, D.; Baishya, L.K. Nutrient Use Efficiency. In Essential Plant Nutrients: Uptake, Use Efficiency, and Management; Naeem, M., Ansari, A.A., Gill, S.S., Eds.; Springer International Publishing: Cham, Switzerland, 2017; pp. 119-146. [CrossRef]

8. Ryser, P.; Eek, L. Consequences of phenotypic plasticity vs. interspecific differences in leaf and root traits for acquisition of aboveground and belowground resources. Am. J. Bot. 2000, 87, 402-411. [CrossRef] [PubMed]

9. Bardgett, R.D. Plant trait-based approaches for interrogating belowground function. Biol. Environ. Proc. R. Ir. Acad. 2017, 117B, 1-13. [CrossRef]

10. Craine, J.M.; Lee, W.G. Covariation in leaf and root traits for native and non-native grasses along an altitudinal gradient in New Zealand. Oecologia 2003, 134, 471-478. [CrossRef]

11. Craine, J.M.; Lee, W.G.; Bond, W.J.; Williams, R.J.; Johnson, L.C. Environmental constraints on a global relationship among leaf and root traits of grasses. Ecology 2005, 86, 12-19. [CrossRef]

12. Kerkhoff, A.J.; Fagan, W.F.; Elser, J.J.; Enquist, B.J. Phylogenetic and Growth Form Variation in the Scaling of Nitrogen and Phosphorus in the Seed Plants. Am. Nat. 2006, 168, E103-E122. [CrossRef]

13. Ryser, P. Intra- and interspecific variation in root length, root turnover and the underlying parameters. In Variation in Plant Growth; Lambers, H., Poorter, H., Van Vuuren, M.M.I., Eds.; Backhys Publishers: Leiden, The Netherlands, 1998; pp. 441-465.

14. Ryser, P.; Lambers, H. Root and leaf attributes accounting for the performance of fast- and slow-growing grasses at different nutrient supply. Plant Soil 1995, 170, 251-265. [CrossRef]

15. Lupton, F.G.H.; Oliver, R.H.; Ellis, F.B.; Barnes, B.T.; Welbank, P.J.; Taylor, P.J. Root and shoot growth of semi-dwarf and taller winter wheats. Ann. Appl. Biol. 1974, 77, 129-144. [CrossRef]

16. Holbrook, F.S. Rooting Depths of Selected Wheat Cultivars; Colorado State University: Fort Collins, CO, USA, 1973.

17. Cholick, F.A.; Welsh, J.R.; Cole, V.C. Rooting Patterns of Semi-dwarf and Tall Winter Wheat Cultivars under Dryland Field Conditions. Crop Sci. 1977, 17, 637. [CrossRef]

18. Wojciechowski, T.; Gooding, M.J.; Ramsay, L.; Gregory, P.J. The effects of dwarfing genes on seedling root growth of wheat. J. Exp. Bot. 2009, 60, 2565-2573. [CrossRef] [PubMed]

19. Subbiah, B.V.; Katyal, J.C.; Narasimham, R.L.; Dakshinamurti, C. Preliminary investigations on root distribution of high yielding wheat varieties. Int. J. Appl. Radiat. Isot. 1968, 19, 385-390. [CrossRef]

20. Qi, Y.; Wei, W.; Chen, C.; Chen, L. Plant root-shoot biomass allocation over diverse biomes: A global synthesis. Glob. Ecol. Conserv. 2019, 18, e00606. [CrossRef]

21. Ubeda-Tomás, S.; Swarup, R.; Coates, J.; Swarup, K.; Laplaze, L.; Beemster, G.T.S.; Hedden, P.; Bhalerao, R.; Bennett, M.J. Root growth in Arabidopsis requires gibberellin/DELLA signalling in the endodermis. Nat. Cell Biol. 2008, 10, 625. [CrossRef]

22. Richard, C.; Christopher, J.; Chenu, K.; Borrell, A.; Christopher, M.; Hickey, L. Selection in early generations to shift allele frequency for seminal root angle in wheat. Plant Genome 2018. [CrossRef]

23. Sanguineti, M.C.; Li, S.; Maccaferri, M.; Corneti, S.; Rotondo, F.; Chiari, T.; Tuberosa, R. Genetic dissection of seminal root architecture in elite durum wheat germplasm. Ann. Appl. Biol. 2007, 151, 291-305. [CrossRef]

24. Xie, Q.; Fernando, K.M.C.; Mayes, S.; Sparkes, D.L. Identifying seedling root architectural traits associated with yield and yield components in wheat. Ann. Bot. 2017, 119, 1115-1129. [CrossRef] 
25. Mac Key, J.; Jordan, W.R.; Zobel, R.W. Lecture 3: Shoot:Root interactions in cereals and grasses. In Plant Roots: A compilation of Ten Seminars Given at Iowa State University in Feburary and March, 1980; Iowa State University, Agronomy Department: Ames, Iowa, 1980.

26. Bektas, H.; Hohn, C.E.; Waines, J.G. Root and shoot traits of bread wheat (Triticum aestivum L.) landraces and cultivars. Euphytica 2016, 212, 297-311. [CrossRef]

27. Siddique, K.H.M.; Belford, R.K.; Tennant, D. Root:Shoot ratios of old and modern, tall and semi-dwarf wheats in a mediterranean environment. Plant Soil 1990, 121, 89-98. [CrossRef]

28. Waines, J.G.; Ehdaie, B. Domestication and Crop Physiology: Roots of Green-Revolution Wheat. Ann. Bot. 2007, 100, 991-998. [CrossRef]

29. Roucou, A.; Violle, C.; Fort, F.; Roumet, P.; Ecarnot, M.; Vile, D. Shifts in plant functional strategies over the course of wheat domestication. J. Appl. Ecol. 2018, 55, 25-37. [CrossRef]

30. Lynch, J.P. Steep, cheap and deep: An ideotype to optimize water and $\mathrm{N}$ acquisition by maize root systems. Ann. Bot. 2013, 112, 347-357. [CrossRef] [PubMed]

31. Jackson, P.; Robertson, M.; Cooper, M.; Hammer, G. The role of physiological understanding in plant breeding; from a breeding perspective. Field Crop. Res. 1996, 49, 11-37. [CrossRef]

32. Richards, R.A. Selectable traits to increase crop photosynthesis and yield of grain crops. J. Exp. Bot. 2000, 51, 447-458. [CrossRef] [PubMed]

33. Singh, V.; Oosterom, E.J.; Jordan, D.R.; Hunt, C.H.; Hammer, G.L. Genetic variability and control of nodal root angle in sorghum. Crop Sci. 2011, 51, 2011-2020. [CrossRef]

34. Uga, Y.; Okuno, K.; Yano, M. Dro1, a major QTL involved in deep rooting of rice under upland field conditions. J. Exp. Bot. 2011, 62, 2485-2494. [CrossRef]

35. Kumar, B.; Abdel-Ghani, A.H.; Reyes-Matamoros, J.; Hochholdinger, F.; Lübberstedt, T. Genotypic variation for root architecture traits in seedlings of maize (Zea mays L.) inbred lines. Plant Breed. 2012, 131, 465-478. [CrossRef]

36. Mace, E.; Singh, V.; Oosterom, E.; Hammer, G.; Hunt, C.; Jordan, D. QTL for nodal root angle in sorghum (Sorghum bicolor L. Moench) co-locate with QTL for traits associated with drought adaptation. Theor. Appl. Genet. 2012, 124, 97-109. [CrossRef]

37. Christopher, J.; Christopher, M.; Jennings, R.; Jones, S.; Fletcher, S.; Borrell, A.; Manschadi, A.; Jordan, D.; Mace, E.; Hammer, G. QTL for root angle and number in a population developed from bread wheats (Triticum aestivum) with contrasting adaptation to water-limited environments. Theor. Appl. Genet. 2013, 126, 1563-1574. [CrossRef] [PubMed]

38. Nyquist, W.E.; Baker, R.J. Estimation of heritability and prediction of selection response in plant populations. Crit. Rev. Plant Sci. 1991, 10, 235-322. [CrossRef]

39. Omori, F.; Mano, Y. QTL Mapping of root angle in F2 populations from maize 'B73' $\times$ teosinte 'Zea luxurians'. Plant Root 2007, 1, 57-65. [CrossRef]

40. Richard, C.A.; Hickey, L.T.; Fletcher, S.; Jennings, R.; Chenu, K.; Christopher, J.T. High-throughput phenotyping of seminal root traits in wheat. Plant Methods 2015, 11, 13. [CrossRef] [PubMed]

41. Mathew, I.; Shimelis, H.; Mwadzingeni, L.; Zengeni, R.; Mutema, M.; Chaplot, V. Variance components and heritability of traits related to root: Shoot biomass allocation and drought tolerance in wheat. Euphytica 2018, 214, 225. [CrossRef]

42. Ekanayake, I.J.; O'Toole, J.C.; Garrity, D.P.; Masajo, T.M. Inheritance of root characters and their relations to drought resistance in rice. Crop Sci. 1985, 25, 927-933. [CrossRef]

43. Singh Gahoonia, T.; Nielsen, N.E. Root traits as tools for creating phosphorus efficient crop varieties. Plant Soil 2004, 260, 47-57. [CrossRef]

44. Fakrudin, B.; Kavil, S.P.; Girma, Y.; Arun, S.S.; Dadakhalandar, D.; Gurusiddesh, B.H.; Patil, A.M.; Thudi, M.; Bhairappanavar, S.B.; Narayana, Y.D.; et al. Molecular mapping of genomic regions harbouring QTLs for root and yield traits in sorghum (Sorghum bicolor L. Moench). Physiol. Mol. Biol. Plants 2013, 19, 409-419. [CrossRef]

45. Shi, L.; Shi, T.; Broadley, M.R.; White, P.J.; Long, Y.; Meng, J.; Xu, F.; Hammond, J.P. High-throughput root phenotyping screens identify genetic loci associated with root architectural traits in Brassica napus under contrasting phosphate availabilities. Ann. Bot. 2013, 112, 381-389. [CrossRef]

46. Kumar, R.; Pandey, S.; Pandey, A. Plant roots and carbon sequestration. Curr. Sci. 2006, 91, 885-890. 
47. Slota, M.; Maluszynski, M.; Szarejko, I. An automated, cost-effective and scalable, flood-and-drain based root phenotyping system for cereals. Plant Methods 2016, 12, 34. [CrossRef] [PubMed]

48. Weaver, J.E. The Ecological Relations of Roots; Carnegie Institution of Washington: Washington, DC, USA, 1919; p. 172.

49. Trachsel, S.; Kaeppler, S.M.; Brown, K.M.; Lynch, J.P. Shovelomics: High throughput phenotyping of maize (Zea mays L.) root architecture in the field. Plant Soil 2011, 341, 75-87. [CrossRef]

50. Das, A.; Schneider, H.; Burridge, J.; Ascanio, A.K.M.; Wojciechowski, T.; Topp, C.N.; Lynch, J.P.; Weitz, J.S.; Bucksch, A. Digital imaging of root traits (DIRT): A high-throughput computing and collaboration platform for field-based root phenomics. Plant Methods 2015, 11, 51. [CrossRef] [PubMed]

51. Clark, R.T.; MacCurdy, R.B.; Jung, J.K.; Shaff, J.E.; McCouch, S.R.; Aneshansley, D.J.; Kochian, L.V. Three-dimensional root phenotyping with a novel imaging and software platform. Plant Physiol. 2011, 156, 455-465. [CrossRef] [PubMed]

52. Bauhus, J.; Messier, C. Evaluation of fine root length and diameter measurements obtained using RHIZO image analysis. Agron. J. 1999, 91, 142-147. [CrossRef]

53. Galkovsky, T.; Mileyko, Y.; Bucksch, A.; Moore, B.; Symonova, O.; Prince, C.A.; Topp, C.N.; Iyer-Pascuzzi, A.S.; Zurek, P.R.; Fang, S.; et al. GiA Roots: Software for the high throughput analysis of plant root system architecture. BMC Plant Biol. 2012, 12, 1-12. [CrossRef]

54. York, L.M.; Slack, S.; Bennett, M.J.; Foulkes, M.J. Wheat shovelomics I: A field phenotyping approach for characterising the structure and function of root systems in tillering species. bioRxiv 2018, 280875. [CrossRef]

55. Burridge, J.; Jochua, C.N.; Bucksch, A.; Lynch, J.P. Legume shovelomics: High—throughput phenotyping of common bean (Phaseolus vulgaris L.) and cowpea (Vigna unguiculata subsp, unguiculata) root architecture in the field. Field Crop. Res. 2016, 192, 21-32. [CrossRef]

56. Araus, J.L.; Cairns, J.E. Field high-throughput phenotyping: The new crop breeding frontier. Trends Plant Sci. 2014, 19, 52-61. [CrossRef] [PubMed]

57. Picon-Cochard, C.; Pilon, R.; Tarroux, E.; Pagès, L.; Robertson, J.; Dawson, L. Effect of species, root branching order and season on the root traits of 13 perennial grass species. Plant Soil 2012, 353, 47-57. [CrossRef]

58. Chen, X.; Ding, Q.; Blaszkiewicz, Z.; Sun, J.; Sun, Q.; He, R.; Li, Y. Phenotyping for the dynamics of field wheat root system architecture. Sci. Rep. 2017, 7, 37649. [CrossRef] [PubMed]

59. Johnson, M.G.; Tingey, D.T.; Phillips, D.L.; Storm, M.J. Advancing fine root research with minirhizotrons. Environ. Exp. Bot. 2001, 45, 263-289. [CrossRef]

60. Bragg, P.L.; Govi, G.; Cannell, R.Q. A comparison of methods, including angled and vertical minirhizotrons, for studying root growth and distribution in a spring oat crop. Plant Soil 1983, 73, 435-440. [CrossRef]

61. Aulen, M.; Shipley, B. Non-destructive estimation of root mass using electrical capacitance on ten herbaceous species. Plant Soil 2012, 355, 41-49. [CrossRef]

62. Ellis, T.W.; Williams, C.; Murray, W.; Paul, K.; Kavalieris, L.; Brophy, J.; Maass, M. Electrical capacitance as a rapid and non-invasive indicator of root length. Tree Physiol. 2012, 33, 3-17. [CrossRef]

63. Amato, M.; Basso, B.; Celano, G.; Bitella, G.; Morelli, G.; Rossi, R. In situ detection of tree root distribution and biomass by multi-electrode resistivity imaging. Tree Physiol. 2008, 28, 1441-1448. [CrossRef]

64. Srayeddin, I.; Doussan, C. Estimation of the spatial variability of root water uptake of maize and sorghum at the field scale by electrical resistivity tomography. Plant Soil 2009, 319, 185-207. [CrossRef]

65. Van Dusschoten, D.; Metzner, R.; Kochs, J.; Postma, J.A.; Pflugfelder, D.; Bühler, J.; Schurr, U.; Jahnke, S. Quantitative 3D analysis of plant roots growing in soil using magnetic resonance imaging. Plant Physiol. 2016, 170, 1176-1188. [CrossRef]

66. Pflugfelder, D.; Metzner, R.; van Dusschoten, D.; Reichel, R.; Jahnke, S.; Koller, R. Non-invasive imaging of plant roots in different soils using magnetic resonance imaging (MRI). Plant Methods 2017, 13, 102. [CrossRef]

67. Jahnke, S.; Menzel, M.I.; Van Dusschoten, D.; Roeb, G.W.; Bühler, J.; Minwuyelet, S.; Blümler, P.; Temperton, V.M.; Hombach, T.; Streun, M.; et al. Combined MRI-PET dissects dynamic changes in plant structures and functions. Plant J. 2009, 59, 634-644. [CrossRef] [PubMed]

68. Garbout, A.; Munkholm, L.J.; Hansen, S.B.; Petersen, B.M.; Munk, O.L.; Pajor, R. The use of PET/CT scanning technique for 3D visualization and quantification of real-time soil/plant interactions. Plant Soil 2012, 352, 113-127. [CrossRef]

69. Mooney, S.J.; Pridmore, T.P.; Helliwell, J.; Bennett, M.J. Developing X-ray computed tomography to non-invasively image 3-D root systems architecture in soil. Plant Soil 2012, 352, 1-22. [CrossRef] 
70. Paya, A.M.; Silverberg, J.L.; Padgett, J.; Bauerle, T.L. X-ray computed tomography uncovers root-root interactions: Quantifying spatial relationships between interacting root systems in three dimensions. Front. Plant Sci. 2015, 6. [CrossRef] [PubMed]

71. Dalton, F.N. In-situ root extent measurements by electrical capacitance methods. Plant Soil 1995, 173, 157-165. [CrossRef]

72. Atkinson, J.A.; Pound, M.P.; Bennett, M.J.; Wells, D.M. Uncovering the hidden half of plants using new advances in root phenotyping. Curr. Opin. Biotechnol. 2019, 55, 1-8. [CrossRef] [PubMed]

73. Pinheiro, P.A.T.; Loh, W.W.; Dickin, F.J. Three-dimensional reconstruction algorithm for electrical resistance tomography. IEE Proc.-Sci. Meas. Technol. 1998, 145, 85-93. [CrossRef]

74. Rossi, R.; Amato, M.; Bitella, G.; Bochicchio, R.; Ferreira Gomes, J.; Lovelli, S.; Martorella, E.; Favale, P. Electrical resistivity tomography as a nonadestructive method for mapping root biomass in an orchard. Eur. J. Soil Sci. 2011, 62, 206-215. [CrossRef]

75. Paglis, C.M. Application of electrical eesistivity tomography for detecting root biomass in coffee trees. Int. J. Geophys. 2013, 2013. [CrossRef]

76. Metzner, R.; Eggert, A.; van Dusschoten, D.; Pflugfelder, D.; Gerth, S.; Schurr, U.; Uhlmann, N.; Jahnke, S. Direct comparison of MRI and X-ray CT technologies for 3D imaging of root systems in soil: Potential and challenges for root trait quantification. Plant Methods 2015, 11, 17. [CrossRef]

77. Zappala, S.; Mairhofer, S.; Tracy, S.; Sturrock, C.J.; Bennett, M.; Pridmore, T.; Mooney, S.J. Quantifying the effect of soil moisture content on segmenting root system architecture in X-ray computed tomography images. Plant Soil 2013, 370, 35-45. [CrossRef]

78. Metzner, R.; van Dusschoten, D.; Bühler, J.; Schurr, U.; Jahnke, S. Belowground plant development measured with magnetic resonance imaging (MRI): Exploiting the potential for non-invasive trait quantification using sugar beet as a proxy. Front. Plant Sci. 2014, 5, 469. [CrossRef] [PubMed]

79. Hainsworth, J.; Aylmore, L. The use of computer assisted tomography to determine spatial distribution of soil water content. Soil Res. 1983, 21, 435-443. [CrossRef]

80. Mairhofer, S.; Sturrock, C.J.; Bennett, M.J.; Mooney, S.J.; Pridmore, T.P. Extracting multiple interacting root systems using X-ray microcomputed tomography. Plant J. 2015, 84, 1034-1043. [CrossRef] [PubMed]

81. Wells, D.M.; Atkinson, J.A.; Bennett, M.J.; Griffiths, M.; Pound, M.P.; Wingen, L.U.; Griffiths, S.; King, J.; Foulkes, M.J.; Gaju, O.; et al. Phenotyping pipeline reveals major seedling root growth QTL in hexaploid wheat. J. Exp. Bot. 2015, 66, 2283-2292. [CrossRef]

82. Fang, S.; Clark, R.T.; Zheng, Y.; Iyer-Pascuzzi, A.S.; Weitz, J.S.; Kochian, L.V.; Edelsbrunner, H.; Liao, H.; Benfey, P.N. Genotypic recognition and spatial responses by rice roots. Proc. Natl. Acad. Sci. USA 2013, 110, 2670-2675. [CrossRef]

83. Iyer-Pascuzzi, A.S.; Zurek, P.R.; Benfey, P.N. High-throughput, noninvasive imaging of root systems. Methods Mol. Biol. 2013, 959, 177-187. [CrossRef]

84. Yan, J.; Wang, B.; Zhou, Y. A root penetration model of Arabidopsis thaliana in phytagel medium with different strength. J. Plant Res. 2017, 130, 941-950. [CrossRef]

85. Finch, J.A.; Guillaume, G.; French, S.A.; Colaço, R.D.D.R.; Davies, J.M.; Swarbreck, S.M. Wheat root length and not branching is altered in the presence of neighbours, including blackgrass. PLoS ONE 2017, 12, e0178176. [CrossRef]

86. Nadeem, M.A.; Nawaz, M.A.; Shahid, M.Q.; Doğan, Y.; Comertpay, G.; Yıldız, M.; Hatipoğlu, R.; Ahmad, F.; Alsaleh, A.; Labhane, N.; et al. DNA molecular markers in plant breeding: Current status and recent advancements in genomic selection and genome editing. Biotechnol. Biotechnol. Equip. 2018, 32, 261-285. [CrossRef]

87. Pace, J.; Gardner, C.; Romay, C.; Ganapathysubramanian, B.; Lübberstedt, T. Genome-wide association analysis of seedling root development in maize (Zea mays L.). BMC Genom. 2015, 16, 47. [CrossRef]

88. Bentsink, L.; Yuan, K.; Koornneef, M.; Vreugdenhil, D. The genetics of phytate and phosphate accumulation in seeds and leaves of Arabidopsis thaliana, using natural variation. Theor. Appl. Genet. 2003, 106, 1234-1243. [CrossRef] [PubMed]

89. Vreugdenhil, D.; Aarts, M.G.M.; Koornneef, M.; Nelissen, H.; Ernst, W.H.O. Natural variation and QTL analysis for cationic mineral content in seeds of Arabidopsis thaliana. Plant Cell Environ. 2004, 27, 828-839. [CrossRef] 
90. Reymond, M.; Svistoonoff, S.; Loudet, O.; Nussaume, L.; Desnos, T. Identification of QTL controlling root growth response to phosphate starvation in Arabidopsis thaliana. Plant Cell Environ. 2006, 29, 115-125. [CrossRef] [PubMed]

91. Kuzyakov, Y.; Domanski, G. Carbon input by plants into the soil. Review. J. Plant Nutr. Soil Sci. 2000, 163, 421-431. [CrossRef]

92. Redin, M.; Guénon, R.; Recous, S.; Schmatz, R.; de Freitas, L.L.; Aita, C.; Giacomini, S.J. Carbon mineralization in soil of roots from twenty crop species, as affected by their chemical composition and botanical family. Plant Soil 2014, 378, 205-214. [CrossRef]

93. Lavallee, J.M.; Conant, R.T.; Paul, E.A.; Cotrufo, M.F. Incorporation of shoot versus root-derived 13C and $15 \mathrm{~N}$ into mineral-associated organic matter fractions: Results of a soil slurry incubation with dual-labelled plant material. Biogeochemistry 2018, 137, 379-393. [CrossRef]

94. Gan, Y.T.; Liang, B.C.; Liu, L.P.; Wang, X.Y.; McDonald, C.L. C:N ratios and carbon distribution profile across rooting zones in oilseed and pulse crops. Crop Pasture Sci. 2011, 62, 496-503. [CrossRef]

95. Silver, W.L.; Miya, R.K. Global patterns in root decomposition: Comparisons of climate and litter quality effects. Oecologia 2001, 129, 407-419. [CrossRef]

96. McLaughlin, S.B.; Wimmer, R. Tansley Review No. 104, Calcium Physiology and Terrestrial Ecosystem Processes. New Phytol. 1999, 142, 373-417. [CrossRef]

97. Cromack, K.; Sollins, P.; Graustein, W.C.; Speidel, K.; Todd, A.W.; Spycher, G.; Li, C.Y.; Todd, R.L. Calcium oxalate accumulation and soil weathering in mats of the hypogeous fungus Hysterangium crassum. Soil Biol. Biochem. 1979, 11, 463-468. [CrossRef]

98. Grabovich, M.Y.; Dubinina, G.A.; Churikova, V.V.; Churikov, S.N.; Korovina, T.I. Mechnisms of synthesis and utilization of oxalate inclusion in the colorless sulfur bacterium Macromonas bipunctata. Microbiology 1995, 64, 630-636.

99. Jones, D.L. Organic acids in the rhizosphere-A critical review. Plant Soil 1998, 205, 25-44. [CrossRef]

100. Frei, M. Lignin: Characterization of a multifaceted crop component. Sci. World J. 2013, $2013,436517$. [CrossRef] [PubMed]

101. Lynch, J.; Whipps, J.M. Substrate flow in the rhizosphere. Plant Soil 1990, 129, 1-10. [CrossRef]

102. Whipps, J.M.; Lynch, J.M. Substrate flow and utilization in the rhizosphere of cereals. New Phytol. 1983, 95, 605-623. [CrossRef]

103. Whipps, J.M. Environmental factors affecting the loss of carbon from the roots of wheat and barley seedlings. J. Exp. Bot. 1984, 35, 767-773. [CrossRef]

104. Whipps, J.M. Effect of $\mathrm{CO}_{2}$ concentration on growth, carbon distribution and loss of carbon from the roots of maize. J. Exp. Bot. 1985, 36, 644-651. [CrossRef]

105. Whipps, J. Carbon loss from the roots of tomato and pea seedlings grown in soil. Plant Soil 1987, 103, 95-100. [CrossRef]

106. Oburger, E.; Jones, D.L. Sampling root exudates-Mission impossible? Rhizosphere 2018, 6. [CrossRef]

107. Oburger, E.; Dell'mour, M.; Hann, S.; Wieshammer, G.; Puschenreiter, M.; Wenzel, W.W. Evaluation of a novel tool for sampling root exudates from soil-grown plants compared to conventional techniques. Environ. Exp. Bot. 2013, 87, 235-247. [CrossRef]

108. Oburger, E.; Gruber, B.; Schindlegger, Y.; Schenkeveld, W.D.C.; Hann, S.; Kraemer, S.M.; Wenzel, W.W.; Puschenreiter, M. Root exudation of phytosiderophores from soil-grown wheat. New Phytol. 2014, 203, 1161-1174. [CrossRef] [PubMed]

109. Hinsinger, P. Bioavailability of soil inorganic $\mathrm{P}$ in the rhizosphere as affected by root-induced chemical changes: A review. Plant Soil 2001, 237, 173-195. [CrossRef]

110. Dakora, F.D.; Phillips, D.A. Root exudates as mediators of mineral acquisition in low-nutrient environments. Plant Soil 2002, 245, 35-47. [CrossRef]

111. Neumann, G.; Römheld, V. Root excretion of carboxylic acids and protons in phosphorus-deficient plants. Plant Soil 1999, 211, 121-130. [CrossRef]

112. Lipton, D.S.; Blanchar, R.W.; Blevins, D.G. Citrate, Malate, and Succinate Concentration in Exudates from P-Sufficient and P-Stressed Medicago sativa L. Seedlings. Plant Physiol. 1987, 85, 315-317. [CrossRef]

113. Römheld, V. Different strategies for iron acquisition in higher plants. Physiol. Plant. 1987, 70, $231-234$. [CrossRef] 
114. Römheld, V. The role of phytosiderophores in acquisition of iron and other micronutrients in graminaceous species: An ecological approach. Plant Soil 1991, 130, 127-134. [CrossRef]

115. Treeby, M.; Marschner, H.; Römheld, V. Mobilization of iron and other micronutrient cations from a calcareous soil by plant-borne, microbial, and synthetic metal chelators. Plant Soil 1989, 114, 217-226. [CrossRef]

116. Rengel, Z. Physiological mechanisms underlying different nutirent efficiency of crop genotypes. In Mineral Nutrition of Crops: Fundamental Mechanisms and Implications; Rengel, Z., Ed.; Haworth Press, Inc.: New York, NY, USA, 1999; pp. 227-265.

117. Asmar, F. Variation in activity of root extracellular phytase between genotypes of barley. Plant Soil 1997, 195, 61-64. [CrossRef]

118. Asmar, F.; Singh Gahoonia, T.; Nielsen, N.E. Barley genotypes differ in activity of soluble extracellular phosphatase and depletion of organic phosphorus in the rhizosphere soil. Plant Soil 1995, 172, 117-122. [CrossRef]

119. Richardson, A.E.; Hadobas, P.A.; Hayes, J.E. Acid phosphomonoesterase and phytase activities of wheat (Triticum aestivum L.) roots and utilization of organic phosphorus substrates by seedlings grown in sterile culture. Plant Cell Environ. 2000, 23, 397-405. [CrossRef]

120. McLachlan, K.D.; Marco, D. Acid phosphatase activity of intact roots and phosphorus nutrition in plants. III. Its relation to phosphorus garnering by wheat and a comparison with leaf activity as a measure of phosphorus status. Aust. J. Agric. Res. 1982, 33, 1-11. [CrossRef]

121. De Vos, C.R.; Lubberding, H.J.; Bienfait, H.F. Rhizosphere Acidification as a Response to Iron Deficiency in Bean Plants. Plant Physiol. 1986, 81, 842. [CrossRef] [PubMed]

122. Jing, J.; Rui, Y.; Zhang, F.; Rengel, Z.; Shen, J. Localized application of phosphorus and ammonium improves growth of maize seedlings by stimulating root proliferation and rhizosphere acidification. Field Crop. Res. 2010, 119, 355-364. [CrossRef]

123. Ding, X.; Fu, L.; Liu, C.; Chen, F.; Hoffland, E.; Shen, J.; Zhang, F.; Feng, G. Positive feedback between acidification and organic phosphate mineralization in the rhizosphere of maize (Zea mays L.). Plant Soil 2011, 349, 13-24. [CrossRef]

124. Zhou, L.L.; Cao, J.; Zhang, F.S.; Li, L. Rhizosphere acidification of faba bean, soybean and maize. Sci. Total Environ. 2009, 407, 4356-4362. [CrossRef]

125. Wu, T.; Zhang, H.; Wang, Y.; Jia, W.; Xu, X.; Zhang, X.; Han, Z.; Wu, T.; Zhang, H.; Wang, Y.; et al. Induction of root $\mathrm{Fe}(\mathrm{III})$ reductase activity and proton extrusion by iron deficiency is mediated by auxin-based systemic signaling in Malys xiaojinensis. J. Expt. Bot. 2012, 63, 859-870. [CrossRef]

126. Nunez, G.H.; Olmstead, J.W.; Darnell, R.L. Rhizosphere acidification is not part of the strategy I iron deficiency response of vaccinium arboreum and the southern highbush blueberry. HortScience 2015, 50, 1064-1069. [CrossRef]

127. Palta, J.A.; Turner, N.C. Crop root system traits cannot be seen as a silver bullet delivering drought resistance. Plant Soil 2018. [CrossRef]

128. Hodge, A. The plastic plant: Root responses to heterogeneous supplies of nutrients. New Phytol. 2004, 162, 9-24. [CrossRef]

(C) 2020 by the authors. Licensee MDPI, Basel, Switzerland. This article is an open access article distributed under the terms and conditions of the Creative Commons Attribution (CC BY) license (http://creativecommons.org/licenses/by/4.0/). 